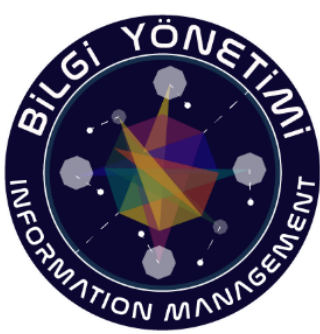

Bilgi Yönetimi Dergisi

Cilt: 4 Sayı: 2 Yıl: 2021

https://dergipark.org.tr/tr/pub/by

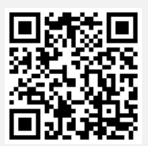

Hakemli Makaleler

Araștırma Makalesi

\section{Makale Bilgisi}

Gönderildiği tarih: 25.08. 2021 Kabul tarihi: $\quad$ 26.10.202

Erken görünüm: $\quad 06.12 .2021$

Yayınlanma tarihi: 31.12 .2021

Article Info

Date submitted:

Date accepted:

Date early view:

25.08. 2021

26.10. 2021

Date published:

06.12 .2021

31.12. 2021

Anahtar sözcükler Arşiv, Arşiv İş Süreçleri,

Yapay Zekâ, Makine Öğrenmesi, Otonom Işslemler

Keywords

Archive, Archival Work

Processes, Artificial

Intelligence, Machine

Learning, Autonomous

Processes

\section{DOI numarasi}

10.33721/by.987197

ORCID

0000-0002-2448-3939

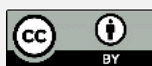

\title{
Arşivler ve Yapay Zekâ
}

\section{Archives and Artificial Intelligence}

\section{Hasan ÖZTÜRK}

Bartın Üniversitesi Edebiyat Fakültesi Bilgi ve Belge Yönetimi Bölümü Araştırma Görevlisi, hozturk@bartin.edu.tr

\section{$\ddot{O} z$}

Bilgi teknolojilerinde yaşanan gelişmeler ve buna bağlı olarak kurumlarda üretilen belge hacminin giderek artması, belgelerin yönetilebilirliğini zorlaştırmıştır. Devasa miktarda arşiv belgelerinin arşivlere intikal etmesi, bu noktada ortaya çıkan yönetim sorunu, teknolojinin kullanımı ile kolaylaşmaktadır. Arşivcilikte teknolojinin sağlamış olduğu yararlara, son dönemlerde kullanımı gittikçe yaygınlaşan yapay zekâ uygulamaları da katkıda bulunmaktadır. Günümüzde ve gelecekte arşivlerde yapay zekânın etkili olarak kullanılmasıyla, farklı değişim ve yeniliklerin ortaya çıkması kaçınılmazdır. Yapay zekâ, arşiv iş ve işlemlerin otonom olarak yürütülmesi, personel değişimine bağlı sorunların ortadan kalkması, arşivlere doğru, hızlı ve kolay bir erişim olmak üzere çeşitli yararlar sağlayacaktır. Bu bağlamda çalışmada, betimleme ve belgesel tarama yöntemleri kullanılarak yapay zekânın arşivcilikteki kullanımlarından örnekler sunularak, mesleki değişim noktasında katacağı yenilik ve gelişmelerden bahsedilmektedir. Aynı zamanda konu ile ilgili yeterli Türkçe literatür bulunmamasından dolayı çalışmanın alanyazınına katkı sağlayacağı öngörülmektedir.

\section{Abstract}

The developments in information technologies and the increase in the volume of records produced in institutions have made it difficult to manage the records. The transfer of a huge amount of archive documents to the archives, the management problem that arises at this point, is facilitated by the use of technology. Artificial intelligence applications, which have become increasingly popular in recent years, also contribute to the benefits of technology in archiving. With the effective use of artificial intelligence in archives today and in the future, it is inevitable that different changes and innovations will emerge. Artificial intelligence will provide various benefits such as autonomous execution of archive work and transactions, elimination of problems related to personnel changes, and accurate, fast and easy access to archives. In this context, in this study are mentioned examples of the use of artificial intelligence in archiving by using descriptive and documentary review methods are presented, and innovations and developments that will be added at the point of professional change. At the same time, it is foreseen that the study will contribute to the literature due to the lack of sufficient Turkish literature on the subject.

\section{Giriş}

Bilgi ve iletişim teknolojilerinde yaşanan gelişmeler, insanlık var olduğundan bugüne kadar kademeli olarak ilerlemeye devam etmektedir. 20. yüzyılda bu alanda meydana gelen en önemli gelişmelerden biri yapay zekânın ortaya çıkışıdır. Yapay zekâ kavramı kısaca, insan tarafından gerçekleştirildiğinde zekâ gerektiren tüm eylemlerin yazılımsal olarak yürütülmesi olarak düşünülebilir. Bu yazılımlar geçmişte sadece filmlere konu olan ütopik varsayllan insana özgü muhakeme etme, karar verme,

\footnotetext{
* Bu makale 2021 yllında Ankara Üniversitesi Sosyal Bilimler Enstitüsü Bilgi ve Belge Yönetimi Anabilim Dalı'nda gerçekleştirilen "Arşivcilikte Yapay Zekâ Kullanımı" adll yüksek lisans tez çalışmasından üretilmiştir.

** Bu makalenin araştırma ve yayın süreci “Araştırma ve Yayın Etiğine” uygun şekilde yürütülmüştür.
} 
öğrenme vb. birçok işlevi yerine getirmektedir. Fakat günümüzde yaşamımızın tam merkezinde yer almaktadır.

Yapay zekâ uygulamaları, yaşamımızda etki ve kapsam alanını giderek arttırmaktadır. Örneğin gündelik hayatın ayrılmaz bir parçası haline gelen akıllı telefonların sesli asistan uygulamaları, yapay zekâ destekli olarak hizmet sunmaktadır. Bunun dışında sürücüsüz otomobiller, mobil cihazlarımız ile sesli arama, izleme alışkanlıklarımıza göre öneri, sosyal ağlarda yüz tanıma, banka ve haberleşme şirketlerinin sesli asistanları vb. sıklıkla kullanılan teknolojiler yapay zekâ uygulamalarıdır. Otonom bir çalışma mantığıyla kullanılan yapay zekâ uygulamaları her alanda zamandan tasarruf sağlayarak kolay, hızlı ve doğru bir işlem hizmeti sunmaktadır.

Kurumlar da hizmetlerini sunarken, yapay zekâ uygulamalarından faydalanarak iş süreçlerini daha verimli ve otomasyona dayalı hale getirmektedir. Bu uygulamaların kullanıldığı yapılar, kütüphane, müze ve arşiv vb. bilgi merkezleridir. Özellikle kültürel bellek kurumlarımızdan arşivlerde yapay zekâ uygulamalarının sağladığı firsatlardan yararlanılması bu kurumlardaki temel hizmet süreçlerini olumlu yönde etkileyecektir.

Bilgiye hızlı ve kolay erişimin sağlanmasıyla dijital ortamda yer alan veri miktarı her geçen gün artmaya devam etmektedir. Uluslararas1 Veri Kurumu (International Data Corporation), 2020 yilına kadar dijital ortamdaki verinin her iki yılda bir iki katına çıkacağını ve 40 Zettabyte (40 trilyon gigabyte) ulaşacağını tahmin etmiştir (Gantz ve Reinsel, 2012, s. 1). Böylesi bir veri hacmi kurumsal işlemlerde üretilen belge miktarına da etki ederek birtakım problemleri beraberinde getirmiştir. Belgelerin seçilmesi, değerlendirilmesi, düzenlenmesi vb. işlemler insan eliyle (manuel) yürütülemeyecek kadar hacimsel büyüklüğe ulaşmışır. Dolayısıyla büyük bir veri yapısının etkin bir şekilde yönetilmesi bağlamında yapay zekâ teknolojileri, önemli katkılar sağlayacaktır.

Arşivcilik iş süreçlerinde kullanılacak uzman sistem, makine öğrenmesi, doğal dil işleme, vb. birçok yapay zekâ uygulamaları arşiv kurumlarında, fon ve serilere ait materyalleri sınıflandırma, indeksleme, özetleme, tanımlama gibi birçok arşiv hizmet ve iş süreçlerini otonom bir yapıya kavuşturacaktır. Ayrıca fiziki ortamda yer alan materyalleri dijitalleştirme, bilgi güvenliğini güçlendirme ve etkili bir dijital arşivleme sistemi kurma işlemlerine de doğrudan fayda sağlayacaktır.

Arşivcilik ve yapay zekâ ilişkisinin kuramsal olarak ele alındığ araştırmalar incelenmiş, uygulama sahasındaki örneklerle yapay zekânın arşiv hizmetlerinin verimliliğine yaptığı katkılar ortaya konulmaya çalışılmıştır. Mesleki değişim noktasında dört temel unsur belirlenmiş olup bu çerçevede arşivciliğin gelişimine yönelik değerlendirmelerde bulunularak sonuç ve öneriler bölümü oluşturulmuştur. Bu çalışmanın bundan sonra yapılacak araştırmalar için temel teşkil edeceği, yol gösterici bir çıkış noktası olacağı öngörülmektedir.

\section{Yapay Zekâ ve İlgili Kavramlar}

Uluslararası Arşiv Konseyi (International Council on Archives) tarafindan Nisan 2019'da düzenlenen Norveç 3. Arşiv Konferansı'nda yapay zekâ "bir makinenin/sistemin herhangi bir faaliyet sırasında bir sonucu tahmin etmek için bilgi aldiğı (yapılandırılmış ve yapılandırılmamış) her şey" olarak tanımlanmıştır (Pratical Guide of Organization, 2018). Bununla birlikte yapay zekâ; insana özgü konuşma, anlama, öğrenme, karar verebilme, akıl yürütme, tahminde bulunma, harekete geçme ve tepki verme gibi insan tarafından gerçekleştirildiğinde yüksek derecede zekâ isteyen birçok bilgi, beceri ve davranışın veri işleme maksadıyla bilgisayar sistemlerine kazandırmayı amaç edinen bir bilim dalı olarak tanımlanabilir.

Yapay zekâ; yapay sinir ağları, uzman sistemler, bulanık mantık ve genetik algoritma olmak üzere çeşitli bileşenlerden oluşmaktadır (Prim, 2006, s. 87-88). Yapay sinir ağları, "insan beyninden esinlenilerek geliş̧tirilmiş, ă̆ırlıklı bağıntılar aracıllğılyla birbirine bağlanan ve her biri kendi bağına sahip işlem elemanlarından oluşan paralel ve dağıtılmış bilgi işleme yapılarıdır. Bir başka deyişle, biyolojik sinir ağlarını taklit eden bilgisayar programları" (Ardıç, 2014, s. 6) olarak düşünülebilir. Uzman sistemler, problem belirleyen, analitik çalı̧an, öğrenilmiş bilgilerden faydalanan ve deneyimlerden çıkarım yapabilen yazılımlardır. Kısaca "belirli bir uzmanlık alanindaki bilgileri zamanla kendisine geliştirebilen yazılımlardır” (Çoban, 2018, s. 11). Bulanık mantık, klasik gruplandırma/kümeleme mantığından ziyade bir gruba ait elemanların tamamen o grubun özelliklerini yansıtmadığını ifade 
etmektedir. "Doğru, yanlış yerine biraz doğru biraz yanlışşseklinde açıllmlar sergiler" (Prim, 2006, s. 88). Son olarak genetik algoritma, Nabiyev'e göre (2016, s. 616) “en iyinin korunumu ve doğal seçilim ilkesinin benzetim yoluyla bilgisayarlara uygulanması ile elde edilen bir arama yöntemidir".

Yapay zekânın birçok uygulama alanı bulunmaktadır. Bu alanlar yapay zekâ bileşenlerinin fonksiyonları çerçevesinde çeşitli amaçlar doğrultusunda gelişmektedir. Makine öğrenmesi, derin öğrenme, örüntü tanıma ve veri madenciliği bu kapsamda yer alan ilgili uygulamalardır. Makine öğrenmesi yapay zekânın genetik algoritma bileşeni ile doğrudan ilişkili bir alandır. Önceden öğrenilmiş olan verilerin herhangi bir probleme veya olaya uygun olarak öğrenme, tahminde bulunma ve uygun modelleme geliştirme algoritmasına makine öğrenmesi denilmektedir. Örnekler ile somutlaştırmak gerekirse, akı1lı telefonlarımızın yüz ve parmak tanıma sistemleri, sosyal medya hesaplarındaki fotoğraf etiketlemelerinde bir arada bulunan kişilerin tespiti doğrultusunda etiket isteğinde bulunma, yine akı1lı telefonlardaki asistan uygulamaları makine öğrenmesinin doğrudan yer aldığı alanlardır.

Derin öğrenme, makine öğrenmesinin kapsamında yer alan bir yapay zekâ teknolojisidir. "Derin ögrenme, geleneksel makine öğrenmesi yöntemlerinden farklı olarak kodlanmış kurallar ile ögrenmek yerine; resim, video, ses ve metinlere ait verilerin simgelerinden otomatik olarak ögrenebilmektedirler" (Yılmaz ve Kaya, 2020, s. 1). Derin öğrenme, yüz tanıma, ses tanıma, karakter tanıma (örneğin Osmanlıca karakter tanıma) sürücüsüz araçlarda, tavsiye sistemlerinde (film, müzik öneri) vb. birçok farklı alanda kullanılmaktadır.

Örüntü tanıma, yapay zekânın, ses, şekil, desen vb. nesneleri tanımlamaya yönelik faaliyet gösterdiği bir takım makine öğrenmesi teknolojisidir. Örüntü tanımanın amacı, nesneleri bir dizi kategori veya sinıfa ayırmaktır (Koutroumbas ve Thedoridis, 2009, s. 1). Hedefi sinıflandırma olan bir disiplin olarak da ifade edilmektedir. Son olarak veri madenciliği ve altında yapılandırılan metin madenciliği, doğal dil işleme uygulamaları bu kapsamda bahsedilmektedir. Arslantekin'e göre (2003, s. 375), veri madenciliği "anlamlı bilgi çıkarmak için otomasyon sürecini kullanan bir yapay zekâdır". Veri madenciliği temelde bilgiye ulaşma çabasını taşımaktadır. Bu bilgiler, amaç ve hedeflere uygun işe yarar faydalı bilgiler olarak düşünülebilir. Verilerden bilgi elde etmek maksadıyla metin madenciliği ve doğal dil işleme uygulamalarından yararlanılmaktadır. "Metin madenciliği, çok büyük belgelerin analizi ve metin tabanlı verinin içerisindeki gizli kalıpların elde edilmesidir" (Dolgun, Özdemir ve Oğuz, 2009, s. 49). Belge üzerinde uygulanan bu işlemler aracılığıyla belgeler arasında ilişkinin belirlenmesi, özet bilgilerin çıkarılması, sınıflandırılması, indeks ve üst veri bilgisi vb. birçok işlem yapılmaktadır. Metin madenciliği çalışmaları, literatürde benzer olarak metin kaynaklı çalışma alanı olan doğal dil işleme ile birlikte bahsedilmektedir. Doğal dil işleme yapay zekânın dil bilim bilgisine dayalı bir çalışma alanıdır. Metin madenciliği çalışmalarında doğal dil işleme kullanımları olmasından dolayı doğal dil işlemeyi bu kapsamda ele almak gerekir (Seker, 2015, s. 31). Bilgisayar sistemlerinin her milletin doğal dillerini anlayıp tepki vermeleri ile ilgilenen bir çalışma alanını ortaya çıkarmıştır. Bu alana doğal dil işleme denilmektedir. Doğal dil işleme insanlar tarafından bilgisayarlara yöneltilen ses ve metinleri işleyip insan ve bilgisayar etkileşimini gerçekleştirmeyi sağlamaktadır. Bu etkileşim neticesinde metin temelli olarak çeşitli işlemler yapılabilmektedir. Adalı' ya göre (2012, s. 4) doğal dil işleme kapsamında yazım yanlışlarının düzeltilmesi, bul ve değiştir, bir metnin özetini çıkarma, bilgisayarla sesli etkileşim, doğal diller arası çeviri vb. işlemler gerçekleştirilmektedir. Bunlara ek olarak Küçük ve Arıc1 (2018, s. 81-83) doğal dil işlemenin kapsamını "metin sınıflandırma, metin ayrıştırma, duygu analizi, bilgi çıkarımı, varlık ismi tanıma, zamansal ilişki çıkarımı, olay çıkarımı, sözcük türü etiketleme, metin sıralama, otomatik harf çevirisi, otomatik soru cevaplama" olarak belirtmişlerdir.

\section{Arşiv İş Süreçlerinde Yapay Zekâ Kullanımı}

Her iş alanında olduğu gibi arşivcilikte de birtakım iş ve işlemler arşivcilik hizmetinin sürdürülmesi için uygulanmaktadır. $\mathrm{Bu}$ işlemler temelde bilgiyi depolamaktan erişime kadar geçen sürecin parçalarıdır. Arşiv belgelerinin seçim ve değerlendirmesinin yapılması, seçilen belgelerin belirli tasnif metotlarına göre düzenlenmesi, mevcut belgeler üzerinden ihtiyaç durumunda koruma sağlanarak depolama işleminin yürütülmesi ve son olarak belgelere erişimin sağlanması olarak temel süreçlerden oluşmaktadır. Arşivciliğin temel fonksiyonlarına ek olarak danışma hizmetlerinin sağlanması, koleksiyonun sunum ve tanıtımının yürütülmesi sürecin diğer aşamaları olarak ele alınabilir. Çalışmanın bu bölümünde, bu süreçlerde yapay zekâ uygulamalarından, proje ve gelişmelerinden bahsedilecektir. 


\section{1. Seçim/Să̆lama ve Değerlendirme}

Seçim işlemlerinde bir uzman sistemin kullanılabilmesi, sistemin karar alma ve yorumlama modüllerine sahip olduğu göz önüne alındığında, sağlama sürecinde karar verici bir role sahip olması beklenilebilir. $\mathrm{Bu}$ konuda örnek bir uzman sistem olan "SelectionAdvisor", Johnston ve Weckert tarafindan geliştirilmiştir. Seçim Danışmanı (SelectionAdvisor), altı seçim kriteri kategorisi kullanır, bu kategoriler (azalan önem sırasına göre) konu, entelektüel içerik, potansiyel kullanım, koleksiyonla ilişki, bibliyografik hususlar ve dil (Hawks, 1994, s. 214) olarak ifade edilmektedir. Bu unsurlar doğrultusunda seçim işlemlerini ilgili kaynak üzerinden gerçekleştirir. Desalvo ve Liebowitz'e göre (1986, s. 29) belge sağlamada uzman bir sistemin rolü, bilgi sistemlerinin sürecin temelini oluşturan kodlama ilkeleri ve prosedürler (ör. kurallar) için uygun bir araç sağlar ve böylece bu kararların doğruluğunu ve tutarlılığını iyileştirmek için gelişmiş iletişimler uygular. Hawks'ın bahsettiği seçim kriterleri, seçim işlemini büyük ölçüde tamamlayacak düzeyde verilerden oluşmaktadır.

Seçim süreci ile birlikte değerlendirme sürecinin de bu çerçevede bulundurulması gerekir. "Değerlendirme, arşiv mevcudunun sistematik olarak oluşturulmasının sağlanması ve daimî olarak saklanması gereken belgelerin belirlenmesi ve korunması açısından anahtar rol üstlenmektedir" (Dearstyne, 2001, s. 38). Harvey ve Thompson dijital belgelerin değerlendirilmesinin otomatikleştirilmesine ilişkin 2010 yılındaki çalışmasında (aktaran Goodman, 2019, s. 8), değerlendirme süreçlerinde manuel yöntemlerin kullanılmaya devam edilmesi durumunda bunun uzun vadede sürdürülemez ve verimsiz" olacağını savunmaktadır. Bu yüzden artan miktarda belgeyi yönetme zorluğu, otonom veya otomatik sistemlere olan ihtiyacı gündeme getirmektedir. Lee'ye göre (2018, s. 3) değerlendirme kararları, (diğer faktörlerin yanı sıra) kullanıcılarla ilgili olacak belge bileşenleri tarafından bilgilendirilecekse, belgelerle ilgili varlıkları belirlemek için doğal dil işlemenin uygulanması faydalı olabilir.

Değerlendirme sürecine ilişkin yapay zekâ destekli yazılım aracı "Archivematica" dır. Archivematica dijital korumayla ilgili bir yazılım olmasının yanında bir değerlendirme modülüne sahiptir. Dosyaların tanımlanmasında uzmandır. Toplu İnceleme Aracı, kişisel tanımlayıcılar gibi sorunlar için belgelerin otomatik olarak incelenmesine yardımcı olmayı amaçlamaktadır (Hutchinson, 2020, s. 165).

Bir diğer değerlendirme modülüne sahip yazılım “ePADD” dır. Stanford Üniversitesi tarafından e-posta arşivlerini bir dizi işlevle işlemek için geliştirilmiştir. Arşivler, yazışmaların belgesel değerini uzun zamandır kabul etmektedir ve e-posta, profesyonel ve genellikle kişisel iletişimin birincil biçimi haline geldiğinden, her türden arşiv kurumları giderek daha fazla e-posta koleksiyonları edinme arayışındadır. Değerlendirme modülü ve işleme modülü aracılığıyla e-posta oluşturuculara ve arşiv kurumlarının çalışanlarına, arşiv koleksiyonlarındaki e-postaların değerlendirilmesini ve işlenmesini etkin bir şekilde gerçekleştirmek için entegre bir araç seti sağlar. Bu araçlar arasında anahtar kelime araması, gelişmiş arama, düzenli ifade araması, çeşitli kategorilerde katmanlı tematik aramaya olanak tanıyan özelleştirilebilir bir 'sözlük araması, arşiv ve diğer metinsel külliyat arasında karşılaştırmalı varlık analizine yardımcı olmak için 'çok varlıklı arama' bulunur. Yazışma listesi araması, görüntü eki araması, posta listesi tanımlaması, grafiksel görselleştirme, kullanıcı notu ve yazışanlara yetkili başlıkları atamak için bir arayüz sağlamaktadır (Schneider vd. 2019, s. 305-307).

Lee'ye göre (aktaran Hutchinson, 2020, s. 15) seçim ve değerlendirme yazılımları, tam teşekküllü karar destek sistemleri olmaktan ziyade, belirli değerlendirmeleri veya kararları desteklemek için hedeflenen araçlar biçimini alabilir. Bu sistemlerin, seçim ve değerlendirme süreçlerinde arşivciye destek mahiyetinde olması gerektiğini vurgulamaktadır. Arşiv yönetimi geniş bir alan olarak düşünülebilirken, belgelerin değerlendirilmesi daha dar bir alanı temsil eder. Günümüzün uzman sistemleri, yargıları içeren, ancak çözülmesi "sağduyu" olarak kabul edilen şeylerin çoğunu içermeyen dar, sinırları iyi belirlenmiş problemlerde en etkili şekilde çalışır (Michelson, 1991, s. 7). Michelson bu görüşüyle uzman bir sistemin belirli konu ve alanlar için uygulanabilir olduğunu ifade ederken yine de sağduyu olarak nitelendirilen insan etkenini yok saymamaktadır. Nitekim benzer bir görüşü Lee de bildirmiştir. Lee'ye göre (2018, s. 4) değerlendirme, çeşitli sosyal, kurumsal ve teknik faktörlere dayanan insan yargılarını içerir. Bu tür yargıları yazılımla değiştirmek ne arzu edilir ne de gerçekçidir. Colavizza vd. (2021, s. 12) yapay zekâ ile arşiv iş süreçlerinin otomatikleştirilerek zengin ve büyüyen bir aktiviteye dönüştügünü ifade ederek değerlendirme ve üst veri oluşturma gibi temel işlemlerde yapay zekânın kısmen veya 
tamamen denenebileceğini ifade etmektedir. Arşiv belgelerinin idari, hukuki, mali vb. arşivsel değerinin bulunması, değerlendirme işlemlerinde yapay zekâ uygulamalarının etkinliğini zorlaştırmaktadır. $\mathrm{Bu}$ noktada makine öğrenmesi uygulamalarının kullanılarak algoritmaların doğru veriler ile eğitilmesi, değerlendirme işlemlerini iyileştirecektir.

Arşiv mevcudundaki belge türlerinin farklılığı, seçim ve değerlendirme sürecini büyük ölçüde etkilemektedir. Fotoğraf, resim, video, harita, kartpostal vb. görsel işitsel materyaller, yapay zekânın makine öğrenmesi ve derin öğrenme tekniklerinin uygulanabilirliği ile tanımlanabilmektedir. Kılıç vd. (2019, s. 318-319) çalışmasında belirttiği üzere yapay zekâ destekli dijital bir arşivde kişi adı ile arşiv arayüzünden sorgulama yapılması durumunda, o kişinin yer aldığ fotoğraf, video ve metinsel belgeleri listelenmektedir. Temelde belge etiketleme işlemlerinden dolayı bu şekilde sonuçlandığı düşünülse de yüz tanıma ve eşleştirme sistemlerinin yani makine öğrenmesi algoritmalarının görsel materyalleri seçebilme yetisi bu tür belgelerin seçimini ve erişimini kolaylaştırmaktadır.

Seçim ve değerlendirme işlemlerinde imha ve saklama süreçlerine ilişkin değerlendirmeler yer almaktadır. Makine öğrenmesinin imha ve saklama süreçlerinde kullanıldığı bazı uygulamalarda görülmektedir. Avustralya Devlet Arşivlerinde yürütülen çalışmada makine öğrenmesinin imha ve saklama işlemlerine nasıl uygulanacağı araştırılmıştır. Bununla birlikte arşiv ekibi, otomatik üstveri oluşturma, anlamsal analiz, taksonomi (sınıflandırma), ontoloji oluşturma ve bağlantılı veri yaklaşımlarını incelemişlerdir (Rolan vd. 2019, s. 194). Bir diğer uygulama New South Wales Eyalet Arşivlerinde yürütülmüştür. Makine öğrenme algoritmalarının imha sürecine ilişkin belgeler üzerindeki uygulanabilirliği test edilmiştir (Rolan vd. 2019, s. 190).

Belge gruplarının arşiv mevcuduna aktarımı için belgelere ilişkin birtakım bilgilerin kaydedilmesi gerekmektedir. Bu bilgiler, belge alınma tarihi, kişi kuruluş bilgileri, belgeler hakkında özet bilgi sunma vb. daha önce bahsedilen bilgilerdir. Metin madenciliği uygulamaları (özetleme, üst veri bilgisi, belge sıralama vb.) vasitasıyla hedef belge grup üzerinden bu bilgilere erişilmesi mümkündür.

\section{2. Düzenleme/Tasnif ve Tanımlama}

Düzenleme işlemlerinde tanımlama anahtar bir rol oynamaktadır. Belgeye ait provenans bilgisi, seri numarası, tarih aralığ $1 \mathrm{vb}$. tanımlayıcı bilgilerin makineler tarafindan gerçekleştirilmesi büyük hacimde tasnif edilmeyi bekleyen arşiv belgeleri için kolaylık ve hız gibi avantajlar sağlayacaktır. Bu noktada belgenin doğru bir şekilde tanımlanması göz ardı edilmemesi gereken önemli bir konudur. Yapay zekâ destekli tanımlama sürecinin doğruluk oranı, uygulanabilirlik açısından fikir verecektir.

Düzenleme süreciyle ilgili Doğal Dil İşleme araçlarının katkıda bulunacağına dair fikirler bulunmaktadır. Bu katkı ile ilgili araştırmalar NAGARA (National Association of Government Archives and Records Administrators) yürütücülügünde sürdürülen projede, elektronik postadaki belgelerin otomatik olarak dosyalanmasını içermektedir (Michelson,1991, s. 5). Nitekim Goodman'a göre (2019, s. 2) doğal dil işleme araçları, arşivcilere düzenleme ve açıklama için yardımcı olabilecek adlandırılmış varlıkları tanımlama yeteneğine sahiptir. Konuları kümeleme yeteneği, arşivcilerin benzer koleksiyonları gruplamasına yardımcı olabilir ve genel içeriğe hızlı bir bakış sağlayarak zamandan tasarruf sağlar ve doğruluğu artırır.

Uzman sistemler de düzenleme sürecinde araştırma ve uygulamalara konu olmaktadır. Michelson'un çalışmasında (1991, s. 5) bahsettiği üzere NAGARA, EXSYS (Expert System Software) yazılımı kullanılarak geliştirilen yaklaşı 320 üretim kuralını içeren bağımsız bir uygulamanın geliştirilmesini destekledi. Elektronik ortamda belgelerin otomatik dosyalanmasını desteklemek için doğal dil işlemeyi araştırmaktadır. Bir diğer uzman sistem kütüphaneler için kullanılan ShelfPro'dur. ShelfPro düzenlemeye ilişkin raf listeleme sağlamaktadır. Raf listeleme; bir öğeye, yer numarasının sınıf işareti kısmının aksine, bir kitap numarası atamakla ilgilidir. Manuel raf listeleme sürecindeki inceleme ve koleksiyon ile ilişki kurma işlemlerinin ardından uygun raf önerisi sunar. ShelfPro'nun otomasyona entegre edilmesi zamandan tasarruf ile birlikte tutarlılığ arttırır (Hawks, 1994, s. 209).

Arşivlerde otomatik sınıflandırma konusunda makine öğreniminin kullanılabilirliğinden bahseden çalışmalar bulunmaktadır (Shang vd. 2019; Payne ve Baron, 2017). Shang vd. (2019, s. 1267) makine öğrenmesine dayalı yapay zekâ sınıflandırma yöntemi kullanılarak, arşivlerde sınıflandırma işlemlerinin uygulayabileceğini belirterek çalışmalarında makine öğrenmesinin arşivlerde sınıflandırma sürecine 
ilişkin teknik bir model önerisinde bulunmuşlardır. Payne ve Baron (2017, s. 2288) makine öğrenmesinin otomatik kategorizasyona (sınıflandırma) ilişkin çeşitli yöntem ve tekniklerin analizini yaparak geniş bir çerçeve sunmuşlardır. İngiliz Ulusal Arşivi (The National Archives) otomatik sınıflandırma konusunda makine öğrenimini kullanan "eDiscovery" yazılımı hakkında bir rapor düzenlemiştir. Rapor, eDiscovery yazılımının, dijital transferlerin bir parçası olarak değerlendirme, seçim ve duyarlılık incelemesi sırasında devlet departmanlarına yardımcı olabileceğini ve sınıflandırma fonksiyonuna sahip bir araç sonucuna varmıştır (Rolan vd. 2019, s. 185-189).

Belgelerin saklanması ve erişiminin sağlanması için dosyalama işlemlerinin yapılması gerekmektedir. Bu konuda 2005/7 sayılı Standart Dosya Planı konulu genelge, elektronik ortamda yer alan belgelerin tüm kurumlarda standart bir dosyalama yöntemi doğrultusunda dosyalanması gerektiğini ifade etmektedir. "Dosyalama sistemlerinde standartlaşma, kurum içinde birlikteliğin sağlanmasina imkân vereceği gibi bunun tüm kurum ve kuruluşlara yaygınlaştırılmasl, ülke çapında etkili ve verimli bir haberleşme sisteminin kurulmasına zemin oluşturacaktır" (Standart Dosya Planı, 2005). Plan aynı konudaki belgelerin bir arada yer almasını ve alt düzeydeki konularında hiyerarşik bir yapıda tutulmasını hedeflemektedir. Fakat kurumlardaki yönetsel farklılıklar, kişilere bağlı meydana gelen yanlışlıklar ve belirsizlikler nedeniyle yanlış kodlar verilebilmektedir (Binici, 2019, s. 119). Söz konusu problemin başlıca sebebi Türkiye'de kurumsal arşiv yapılarının yeterli olgunlukta olmaması ve buna bağlı uygulama standartının gelişmemesidir. Standart Dosya Planı (SDP) sınıflandırma işlemlerini doğru bir şekilde uygulanabilmesi için dış etkenlerden bağımsız otonom sistemlerden, yani yapay zekâ uygulamalarından faydalanması gerekmektedir. Bu noktada makine öğrenmesi kullanılarak yeterli miktarda doğru verinin eğitilmesi ile belgelerin sınıflandırma işlemleri sağlanabilmektedir. Binici tarafindan gerçekleştirilen çalışmada (2019, s. 123) belirli bir veri (belge) havuzu üzerinde gerçekleştirilen makine öğrenmesi uygulaması ile belgelere atanan SDP numarasının \%87,72 oranında doğruluğa ulaştığı ifade edilmiştir. Böylelikle makine öğrenmesi uygulamalarının otomatik sınıflama konusunda etkili olduğu görülmektedir. Bununla birlikte metin madenciliği yöntemlerinin belge üzerinden önemli bilgileri (tarih, kişi, dosya no, kurum/birim bilgisi vb.) ayırt etmesi ve özellikle belge içeriği ile ilgili konu bilgisinin SDP planı kapsamında dikkate alınması, makine öğrenmesi ile otomatik SDP numaralarının verilmesi sürecine katkı sağlayacaktır. Çil ve Aydın çalışmasında (2019, s. 204) "Metin madenciliği ile belge içeriğinden bilgi çıkarımı yapıldıktan sonra belgelere, sınıflandırma işlemi için makine öğrenmesi" uygulanabileceğini ifade etmektedirler. Dosyalama işlemlerinin otonom bir alt yapıya kavuşturulmasıyla; kurumsal, bireysel ve yönetsel belirsizlik ve hataların ortadan kaldırılması ve belgelerin ilgili dosya numarasına altında sınıflayarak tek biçim olarak düzenlenmesini kolaylaştırmaktadır. Dolayısıyla otonom ve doğru bir sınıflama işlemi sağlanacaktır. Dosyalanan arşiv belgesine ilişkin saklama planlamasının yapılması ve bu planlamanın da yapay zekâ destekli bir sistemle ile entegre edilmesi gerekmektedir.

Saklama Planları, yasal, idari, mali veya tarihi ihtiyaçların giderilmesi maksadıyla belgenin ne kadar süre ile saklanması gerektiğini belirten dokümanlardır. Bu dokümanlar, belgeyi muhafaza etmek, devretme, imha etme gibi işlemlere ilişkin süreleri belirten ve hangi belgelerin ne kadar süre ile nerede saklanacağı konusunda yönlendirici bilgi veren rehberlerdir. Saklama planları oluşturulurken arşiv belgelerinin yeniden kullanılabilirlik değeri göz önünde bulundurularak belgenin üretildiği kurum/birim doğrultusunda SDP'de yer alan 000-999 aralığındaki genel ve alt konu başlıkları doğrultusunda sınıflandırma numarası dikkate alınarak, belirtilen saklama süresi uygulanmalıdır. Dolayısıyla saklama planlamalarının yapılması SDP kapsamında sınıflandırma işlemlerine bağlı olarak değerlendirilmektedir. Örneğin hukuk işleri genel sınıflama başlığı altında, saklama süresi ve kodu verilecek herhangi bir belgenin ne kadar süre ile saklanması gerektiği konusunda, makine öğrenmesi uygulamalarının kullanımı, çok miktarda doğru verinin eğitilmesi ve buna bağlı olarak işlemlerin otonomlaşması mümkündür. Sinıflandırma konusunda sunulan örneklerden anlaşıldığı üzere yapay zekâ uygulamalarının bu alanda kullanılabileceği görülmektedir.

\section{3. Koruma ve Depolama}

Koruma süreci, belge kayıt ortamlarının tamamen dijital ve/veya fiziki ortamda yer almamasından dolayı iki farklı durumu ortaya çıkarmaktadır. Bu yüzden fiziksel ve dijital ortamda depolanan belgelerin korunması ayrı ayrı ele alınmalıdır. Yapay zekânın fiziksel ortamdaki arşiv belgelerinin korunması 
hususunda bir uzman sistemin merkezi iklimlendirme fonksiyonuna sahip işlev göstereceğinden bahsedilmektedir. Nitekim Yajian, Chuwu ve Luan'ın çalışmasında (2002, s. 858) bahsettiği üzere arşiv kuruluşunun sicaklık ve nem kontrol sistemini kontrol etmek için uzman tabanlı çok modlu anahtarlama kontrolü bulunduğu ifade edilmektedir. Genellikle sıcaklık ve nemin kontrolü, uzman arşivcinin denetimiyle uygun derecelendirmenin ayarlanmasıyla kontrol edilmektedir. Bu düzenleme büyük dikkatsizlikler, yavaş tepki ve zayıf bir sağlamlık gibi birçok sınırlamalara sebep olmaktadır. $\mathrm{Bu}$ nedenle, performansı daha da artırmak ve güvenilir, daha akıllı kontrol yöntemi geliştirilmelidir (Yajian, Chuwu ve Luan, 2002, s. 859). Çok-modlu anahtarlama kontrolü (multi-mode switching control) adı verilen bu uzman sistemin otonom bir koruma düzeni sağlaması ve böylelikle dış etkenlerden bağımsız bir kontrol istikrarının sürdürülmesi sağlanacaktır. Bir diğer uzman sistem California Eyalet Kütüphanesi Vakfı tarafından pazarlanan CALIPR (California Preservation Program)'dır. Bu ihtiyaç değerlendirme aracı, bir koruma danışmanının koleksiyonun koruma ihtiyaçlarını değerlendirmeye, ölçmeye ve önceliklendirmeye yardımcı olacak bazı uzmanlıklar sağlar (Hawks, 1994, s. 216). Koruma yaklaşımı bakımından arşivcilik için de benzer mantıkta işlemlerin bulunması uzman sistemin bilgi tabanı modülünün arşivciliğe entegre edilmesiyle uygun bir koruma değerlendirilmesinin sağlanması mümkündür.

Son yıllarda kolaylıkla değiştirilebilen belgelerden, fotoğraflardan, ses kayıtlarından yayılan haberlerin dijital ortamdaki belge koruma güvenilirliğinin tekrar gözden geçirilmesini gerekli kılarak araştırmaları bu yönde yoğunlaşmıştır. Dijital koruma araştırmacılarının odak noktalarından biri bu dijital doğan nesnelerin bütünlüğünü garanti etmektir- yani arşivde saklanırken değiştirilmeden kalmalarıdır (Green vd. 2019, s. 3). Fiziki ortamda yer alan belgelerin değiştirilmesinde belirgin farklılıkları görünür kılması bakımından zor iken dijital belgelerin değiştirilmesi kayıt ortamının doğası gereği kolay ve mümkündür. Dijital veriler elle tutulamaz ve kurcalanmaya açık bırakılır ve dijital formatlar sürekli geliştikçe ve içeriğin güncellenmesi gerektiğinden, dosyaların kazara bozulma riski vardır (Archangel, 2021). Dijital ortamdaki belgenin orijinalliğini kaybetmeden korunması ve bütünlüğünün sürdürülebilirliği bu noktada önem kazanmaktadır. Arşivler, kamu kurumları tarafından oluşturulan büyük miktarda dijital materyali korumak için çalışırken, kaydın ve üst verilerinin bilmeden değiştirilmemesini sağlamaya, koruma ve sunum hazırlık çalışmalarının bir denetim izni sağlamak için yapılan her türlü eylemi kaydetmeye dikkat ederler (Green vd. 2018, s. 4). Koruma işlemlerinin son dönemlerde yaygın olarak bahsedilen blokzincir teknolojisi yardımıyla etkin ve güvenilir bir koruma sağlayacağı düşünülmektedir. Blokzincir, işlemlerin güvenilirliğini ağdaki paydaşlar tarafından doğrulandığı dağıtık, şeffaf, değiştirilemez ve güvenli bir veri yapısı sunar. Blokzincirin güvenilirliği arşiv korumasına yönelik bir teknoloji olarak değerlendirilebilir (Lemieux, 2016, s. 19). Blokzincir oluşturma ve depolama sırasında belgeleri korumak için kriptografi kullanan yeni bir tür dağıtılmış defter teknolojisidir (Galiev vd. 2018, s. 84). $\mathrm{Bu}$ teknoloji kriptografi (şifreleme) vasitasıyla dijital imza ile çalışmaktadır. Bununla birlikte belge yönetimi temelli olarak blokzincirin bazı uygulama alanlarından bahsedilmektedir. British Columbia üniversitesinden Lemieux tarafından yayınlanan bir rapora göre (2016, s. 12-14) blokzincir; kimlik yönetim, varlık mülkiyetinin tescili, noter tasdiki, dijital imza, gizlilik koruması, provenans (kaynak) takibi ve akıllı sözleşmeler gibi belge yönetiminin aktif rol oynadığı uygulama alanlarında faaliyet göstermektedir.

Blokzincir teknolojisinin ARCHANGEL ve ARCHAIN projeleri olmak üzere iki uygulama alanı arşiv belgeleriyle ile ilgili koruma sürecini içermektedir. Arşivlerde blokzincir teknolojisi konulu ARCHANGEL projesi, dijital koruma konusunda açıklayıcı bilgiler içermektedir. The National Archives tarafından yürütülen ARCHANGEL projesi, dağıtılmış defter teknolojisi (yaygın olarak blokzinciri olarak bilinir) ve makine öğrenimi tarafindan sunulan olanakları ve doğuştan dijital materyalin sunduğu güven, bütünlük ve özgünlükle ilgili zorlukları nasıl ele alabileceklerini araştırmaktadır (Green vd. 2019, s.2). Blokzincir, birden fazla kişinin yetkili olduğu bir veri tabanı üzerinden herkesin kontrol edip eklemeler yapabildği, ancak kimsenin değiştiremediği bir sitem yapısını sunmaktadır (Archangel, 2021). ARCHANGEL, Blokzincir teknolojisini, arşivden alınan belgelerin parmak izine göre eğitilmiş sinir ağları ile birleştirmektedir (Archangel, 2021). Blokzincir, arşivlere belgeleri orijinal olarak savunmak için kullanabileceği bir kalkan sunar (Green vd. 2018, s. 4) Arşiv dosyasında yapılacak en ufak bir bit değişikliği göz ardı edilmeden etkili bir koruma sağlayan algoritma geliştirmektedir. Bu şekilde, bir araştırmacı, belki onlarca yıl önce kaydedilen orijinal sağlama toplamını almak için blokzincirindeki arşiv kaynağını arayabilir ve bunu yeni indirdikleri kaydın sağlama toplamı 
ile karşlaştırabilir (Green vd. 2019, s. 8). Proje yoluyla anayasa mahkemesinin belgeleri ve video kayıtlarının kendi sistemlerinde saklanmasını sağlamıştır. Elektronik ortamda yer alan videoların, arşivleme güvenliği, değişmezliği ve bütünlüğü konusunda zorlukların meydana gelmesi, blokzincir teknolojisinin video güvenilirliği ve bütünlüğü konusunda işlevsel bir rol oynamasına yol açmıştır (Bui vd. 2019, s. 2793).

Bir diğer proje olan ARCHAIN Tataristan Cumhuriyeti Devlet Arşivleri Koruma Komitesi tarafindan yürütülmektedir. Projenin görevi, arşiv süreçlerinde blokzincir teknolojisinin kullanım olasılığını araştırmak ve bir arşivdeki bilimsel ve teknik dokümantasyon zorunlu bir kopyasının aktarılması için bir yazılım prototipi oluşturmaktır (Galiev vd. 2018, s. 85) Nitekim proje çıktısı olarak blokzincirin arşivler için uygulanabilirliğinin tanımlanması, yazılım uygulamasının ve mimarisinin sunumu için bir prototip geliştirilmiştir.

Blokzincir çeşitli üstveri bilgilerinin bloğa kaydedilmesini sağlamaktadır. Çiçek ve Sağlık’a göre (2019, s. 156) "İmza, dosya ad ya da tek biçim tanımlayıcı, içeriğin iz değeri, arşivcinin notu, yükleme tarihi, versiyon bilgisi gibi üstverilerle birlikte blokzincirlere kaydedilir. Bu veriler son blokla ilişki kurularak blokzincirde saklanır" Özetle blokzincir teknolojisi belgeleri tespit edilmeden değiştirilmeyen veya silinmeyen bir "blok" olarak mühürleyip güvenilir bir depolama imkânı sunar. Bu teknoloji, dijital kamu arşivlerinin sürdürülebilirliğini sağlayarak, arşivlerde belgeleri paylaşılabilir bir yapı ile bütünlügünü garanti altına alabilir (Green, 2018). Dolayısıyla blokzincir teknolojisi, yapay zekânın (özellikle makine öğrenmesi) kullanılması ile belgelerin güvenliğini sağlamada örnek bir teknoloji olarak düşünülebilir.

\section{4. Belge Erişimi}

Belgelerin depolanması ve erişime sunulması dijital çağın ortaya çıkardığı internet ve bilgisayar teknolojileri vasıtasıyla veritabanları aracılığıyla sağlanmaktadır Ülkemiz arşiv hizmetlerinin yürütücü kurumu Devlet Arşivleri Başkanlığı, arşiv mevcuduna erişim hizmetini BETSİS (Belge Tarama Sistemi) üzerinden de sağlamaktadır. Dolayısıyla arşivlerden yararlanmak isteyen kullanıcıların veri tabanlarında bilgiye erişim becerilerine sahip olması gerekmektedir.

Milyonlarca kaydın yer aldığı veri tabanları, çeşitli arama tekniklerini ve bu tekniklerin uygulanabildiği bir sistemi gerekli kılmıştır. Bu sistemlerde bilgi arama işlemi, kullanıcının bilgi sistemi ara yüzüne anahtar kelimelerle arama ifadelerini sorgulatarak, bilgi havuzundaki üstveri ögelerinin benzerlik esasına göre ilişkili sonuçları listelemesiyle gerçekleşir. Basit düzeyde gerçekleşen bu erişime yapay zekâ destekli uygulamalarının entegre edilmesiyle erişim hızı ve kolaylığı sağlandığı görülmektedir. Nitekim yapay zekâ bileşenlerinden "genetik algoritma mevcut verilerdeki bir grup çözüm arasında en iyi çözümü bulmak için rastgele aramalarda önemli bir tekniktir" (Abualigah ve Hanandeh, 2015, s. 20) Başlı başına bir arama yöntemi olan genetik algoritma, en iyinin korunmasını esas alarak tarama sonuçlarının iyileştirilmesini sağlar ve harf-kelime hatalarının düzeltmesini gerçekleştirir.

Bilgiye erişimde katkı sağlayan bir diğer yapay zekâ uygulaması doğal dil işlemedir. Genellikle doğal dil işleme, metin eşleşmesinden (sembol, kelime, cümle vb.), içerik eşleştirmeye (anlam) kadar geniş bir yorumlama becerisine sahiptir. Bu teknoloji yardımı ile veri tabanları üzerinden taramalarda yardımcı bazı işlemler gerçekleşmektedir. Belgelerin doğal dil yardımıyla temsil edilebilmesi için içeriklerinin anlamlandırılması gerekmektedir. "Metin belgeleri çoğunlukla sözdizimsel veya anlamsal bağlam olmaksızın doğal dil terimleriyle temsil edilir" (Mandl, 2009, s. 152). Greenberg' in "Doğal Dil İşleme'nin Arşiv Özelliklerine ve Amaçlarına Uygulanabilirliği” adlı çalışmasında (1998, s. 402-403) belirttiği üzere bu işlemler şu şekildedir:

1. Boolean, bitişik ve yakınlık operatörleri, iki veya daha fazla arama terimi kullanıldığında "ve" "veya" "yakın" ve "beş kelime içinde" gibi sözlü komutlarla aramayı hassaslaştırır;

2. Kök oluşturma algoritmaları, son ekleri kısaltan ve / veya arama terimlerinden önekleri ve ekleri ortadan kaldırır;

3. Niord algoritmalarını durdurma, "the", "an" ve "a" gibi herhangi bir içerik değeri olmayan, işleme etki etmeyen kelimelerini çıkartır;

4. Sözcüksel varyasyon geliştirmeleri, yapılandırılmış bir kelime dağarcığı aracı veya 'ftogef' kelimesine benzer bir eşanlamlılar sözlüğü ile çalışırken sorgu işlemine daha alakalı terimler 
sunmaktadır. Yani anlamsız bir ifade üzerinden anlamlı kelimeleri benzerlik veya eş anlam sözlüğü içerisinden karşılaştırıp en uygun olanı bulmak fonksiyonuna sahiptir.

5. Terim sıklı̆̆ı: F hesaplamaları, bir terimin veya bir terim grubunun bir belgede kaç kez göründüğ̈nü belirler;

6. Trriti ağırlıklandırma algoritmaları, terimlere içerik değerlerine göre sayısal değerler veya ağırlıklar atar (önemli kişiler, yerler, ana olay adları, önemli içerik terimleri diğer tüm belge terimlerinden daha yüksek sayısal değerler alır. Bağlaçlara genellikle hiçbir değer atanmaz ve genellikle sorgu-belge benzerliği hesaplamasından çıkarılır).

7. Kümeleme algoritmaları, temelde belgeleri veya terimleri kategorilere ayırmaktadır (ör. anahtar kelimeler, yazarlar, alıntılar veya diğer önemli belge öznitelikleri).

Doğal Dil İşleme aynı zamanda aramalara ilişkin sonuçları en ilgiliden alakasız olana doğru sıralamaktadır. Doğal Dil İşleme'nin sağlamış olduğu bu işlevler, arşivlerde tarama sonuçlarının basit benzerlik eşleştirme yaklaşımlarının ötesinde ayrıntı ve gereklilikleri dikkate alan bir kolaylık sağlamaktadır. Tarama işlemlerinde hız ve kolaylık gibi faydalara ek olarak "elektronik arşiv ortamında Doğal Dil İşleme ile ilgili bu kadar heyecan verici olan şey, uygun maliyetli, zamanında ve tutarl indekslemeye katkıda bulunabilmesidir; insan hatasinda azalma ve uygun, kullanicı dostu ve kapsamlı erişim" (Greenberg, 1998, s. 412) gibi çeşitli faydaları bulunmaktadır. Bu faydaların ardından arşivcilikte kullanılan bilgi erişim araçları (özetleme, indeksleme, kataloglama) ile ilgili yapay zekânın katkılarının neler olduğu ortaya konulmalıdır.

Arşivcilikte belge özetleme işlemleri uzun zamandan beri insana dayalı olarak sürdürülmektedir. Teknolojik gelişmeler ile birlikte özetleme işlemlerinin yürütüldüğ̈̈ basit düzeyde uygulamalar cümle seçerek ve yorumlayarak özetleme (Uzundere vd. 2008, s. 1) şeklinde iki farklı unsur temel alınarak çeşitli özetleme işlemleri bulunmaktadır. Bu işlemin makineler tarafindan daha kapsamlı ve otonom bir şekilde yapılması yapay zekâ uygulamalarının kullanımı ile mümkün hale gelmektedir. Yapay zekâ, belge özetlemeye ilişkin DDİ ve metin madenciliği yazılımlarından faydalanmaktadır. Bir belgenin ve/veya metnin özetini çıkararak metni anlama ve içeriğindeki bilgiyi çıkarma yoluyla arşivcilik esaslı tüm bellek kurumlarında bilgiye erişime katkı sağlayacaktır.

Kapsamlı bir bilgiye erişimde bir belge ve belge grubuna ilişkin tüm içeriğin dizin terimlerinin temsil edilmesi gerekmektedir. DDİ arşiv belgelerini otomatik olarak işler ve çok kısa bir zaman diliminde belge temsilini oluşturur. İnsan indeksleyicisinin deneyimlemesinden çok daha uygun ve daha ucuz bir yöntemdir (Greenberg, 1998, s. 412) Elektronik arşiv ortamında DDİ ile ilgili en önemli özelliklerden birisi, uygun maliyetli, zamanında ve tutarlı indeksleme yeteneğine sahip olmasıdır. Böylelikle insan hatasını en aza indirerek, kullanıcıya kolay ve kapsamlı bir erişim sunar (Greenberg, 1998, s. 412) İndeksleme yaparken eş anlamlı ve anlamsal olarak birbirleriyle ilişkili terimleri önermek için sözcüksel bir aracı da bu sürece dahil edebilir. Eş anlamlılara örnek olarak "dil" kelimesi için "lisan" ifadesini önerebilir. DDİ her zaman en tutarlı ve iyi sonucu vermezken geleneksel indeksleme yöntemlerindeki maliyet yüksekliği sebebiyle kullanılabilecek en iyi erişim aracını sunmaktadır.

Bir erişim aracı olan kataloglar ile ilgili birçok uzman sistem var olduğundan, yönlendirme ve öneri yoluyla, kataloglama için bilgiye dayalı kurallar uygulayarak uzman sistemler kurabileceğimizden bahsedilmektedir. Hirtle'nin çalışmasında (1987, s. 80) bahsettiği üzere uzman bir kataloglama sistemi, kuralları AACR2'de somutlaştırır ve ardından bunları otomatik olarak kataloglamak için bir kitap veya arşiv koleksiyonuna uygular. Kuralların uygulayan katalogçu insan yerine bu kuralları uygulamaya geçiren bir yazılım fikrini ileri sürmektedir. Uygulama sahasında uzman kataloglama sistemlerinin kütüphaneler için geliştirilmiş yazılımları bulunmaktadır. MAPPER uzman kataloglama sistemi, acemi harita kataloglayıcılarına uzman tavsiyesi sağlamak ve harita kataloglamada geleneksel eğitimi geliştirmek amaciyla geliştirilmiş bir uzman sistemdir. CATALSYT uzman kataloglama sistemi, erişim noktalarının seçimi ve biçimi konusunda katalogçuya danışman olarak hizmet veren daha basit, daha az karmaşık bir sistemdir. CatTutor uzman kataloglama sisteminin birincil amacı, acemi katalogçuları bilgisayar dosyaları için bibliyografik belgeler oluşturma konusunda eğitmektir (Hawks, 1994, s. 210). CatTutor'un aynı zamanda kullanıcıya bir takım kataloglama işlevlerini öğretmek ve tanıtma gibi özellikleri vardır. 
AACR2, uzman bir arşivci tarafından anlaş1labilir olabilirken makineler için anlaşılabilir değildir. Kataloglama, katalogçu tarafinda yüksek derecede yarg1 ve yorum gerektirdiğinden dolayı, tam otomatik bir uzman kataloglama sisteminin geliştirilmesi, yalnızca üretim kuralları biçimindeki, uygulamalarda açı olan ve dolayısıyla bir bilgisayar tarafindan anlaşılabilir olan yeni bir kataloglama kuralları kümesi gerektirecektir (Hirtle, 1987, s. 80-81). Bu noktadan hareketle kataloglama becerisine sahip bir arşivcinin kontrolünde bir uzman sistemin uygulanabilirliği daha makul bir seçenek olarak görülmektedir. Her belge için farklı durumların bulunması, çoğu zaman otonom bir yardımın ötesinde birtakım yorum ve deneyim içeren süreçleri de barındırmaktadır. Uzman bir sistemin deneyimlerden öğrenmesi ve örtük bilgiyi içerebilme fonksiyonunun bulunması, kataloglama süreçlerinin günden güne deneyimlenmesi ile birlikte gelişimini artarak devam ettirebileceği muhtemeldir.

Makine öğrenmesi tekniklerinin bilgiye erişimde çeşitli katkıları bulunmaktadır. $\mathrm{Bu}$ teknikler yardımıyla insan kataloglayıcılar tarafından daha da doğrulanan ve artırılan daha zengin üst veriler, görsel-işitsel malzemeler için arama seçeneklerini önemli ölçüde geliştirebilir, bu malzemelerdeki çeşitli ögeler üzerinde gezinmeyi ve tanımlamayı kolaylaştırabilir ve bağlamları hakkında daha iyi bilgi sağlayabilir (Bohyun, 2021, s. 40). Bohyun çalışmasında (2021, s. 41) arşivlerin erişim konusunda yetişmekte zorlandığ görsel-işitsel materyaller için geniş ölçekte zengin üst veriler oluşturmak, temel öge düzeyinde açıklamanın çok sayıda görsel ögeye eklenmesini hızlandırmak ve arşiv materyallerinden metinsel, işitsel, görsel veya tablo verileri olarak tam içeriği çıkarmak gibi görevlere makine ögrenmesinin ciddi katkıları olacağından bahsetmektedir. Makine öğrenmesinin uygulanabilirliği arşiv materyalinin dijital olarak üretilmiş veya sonradan dijitalleştirilmiş olmasına bağlıdır. Bu dijital varlıkların doğru bir şekilde tanınması, veri kümesindeki doğru örneklerin fazlalığına bağlı olarak algoritmaların eğitilmesiyle sağlanmaktadır.

\section{5. Danışma Hizmetleri}

Danışma hizmetleri ile ilgili kullanılan uzman sistemlerin kütüphanelerde çok sayıda örneği (araştırma, işaretçi, çevrimiçi referans yardımı, cevaplayıcı, PLEXUS) bulunmaktadır (Selçuk, 2019, s. 21). Bu sistemler işlemlerini, kullanıcı tarafindan sorulan sorular neticesinde uzman danışma sisteminin, bilgi ihtiyacını belirleyip uygun kaynağa yönlendirme görevini gerçekleştirmesiyle yürütülmektedir. Çalışma mantığı olarak bir chatbot sistemine benzetilebilir. Kullanıcının bilgi uzmanı yardımı gerekmeksizin uzman bir sistem yardımıyla zaman ve mekân sınırı olmadan danışma hizmeti alması mümkün hale gelmektedir. Uzman sistemin danışma hizmetlerine sağlayacağı faydalar şu şekilde özetlenebilir:

1. Uzman bir sistem, kullanıcıya deneyimli bir danışma hizmeti veren arşivcinin veya arama aracısının (kurumsal veri tabanı) sunabileceği yardımları sağlar.

2. Uzman bir sistem, gelecekte geliştirilebilecek bilgi tabanında deneyimli arşivcilerin danışma hizmetleri uzmanlığını toplar ve karşılaşabileceği problemlere geçmiş deneyimler yoluyla hızla yanit verir.

3. Uzman bir sistem, danışma hizmeti sunan bir arşivcinin problem çözme becerilerini ve ayrıca danışma mülakatı gibi kullanıcının bilgi arama davranışını bilgi tabanı içerisine kaydeder. Kullanıcının özel olarak ilgi alanının bilinmesiyle sorulara yönelik cevaplar, kullanıcı ilgi alanı doğrultusunda paralel olarak gelişmektedir.

4. Uzman bir danışma sistemi, bilgiye erişim süresini hızlı bir şekilde gerçekleştirmek için güçlü bir arama motoruna sahiptir.

Hirtle çalışmasında (1987, s. 84) arşivler için basit ve pratik bir uzman referans sistemi, bir Optik Karakter Tanıma (Optical Character Recognition-OCR) tarayıcısı kullanılarak büyük olasılıkla makine tarafından okunabilir formatta okunan bir bulma yardımcıları veri tabanına bağlanmış bir uzman sistem kabuğundan oluşacağından bahsetmiştir. Arşiv dermesinin OCR ile taranarak, gereksinim duyulan belgenin içerik ve üst veri bilgisinden ilgililik esasına göre erişilmesini sağlar. Temel düzeyde arama ve eşleşme faaliyetleri de bu mantık çerçevesinde gerçekleştirilir. Dolayısıyla danışma uzman sisteminin arşiv ve diğer bellek kurumlarının dermelerine entegrasyonunda, OCR başlıca etki sağlamaktadır.

Danışma hizmetleri, kullanıcıya ilişkin yönlendirme ve öneride bulunma adımlarını içerir. Arşiv mevcudundaki materyallerin kullanıcılara özel olarak önerilmesi ancak yapay zekâ teknikleri ile 
mümkündür. Büyük bir veri havuzundaki bilgilerin veri madenciliği yoluyla analiz edilip yönelimlerin ortaya çıkarıldığı günümüzde siyaset, finans, pazarlama gibi birçok alanda örnekleri bulunmaktadır. Örneğin bir siyasi parti, seçim çalışmaları için sosyal medya ağları üzerinden insanların yönelimlerini bu yöntemler vasıtası ile kolaylıkla çıkarmaktadır (Safalı, Avaroğlu ve Ergen, 2018, s. 1). Arşiv temelli bir bilgi merkezi için de benzer durumdan bahsetmek mümkündür. Kullanıcı yönelimlerinin ortaya çıkarılması ile çalışma-ilgi alanları tespit edilmesi ve uygun kaynak önerisinin sunulması, veri madenciliği teknikleri ile kullanıcı grupları üzerinden ayırt edici bilgilerin (bölüm, çalışma alanı, yayınlar vb.) işlenmesi ile mümkün olabilmektedir.

\section{6. Koleksiyon Sunum ve Tanitımı}

Günümüzde arşivlerde tanıtım faaliyetleri “Web 2.0” teknolojileri vasıtasıyla sosyal ağlar üzerinden kurumların kullanıcılara ulaşmasını kolaylaştırmışıtır. Arşivler, Facebook, Twitter, Instagram, Youtube vb. sosyal ağ platformlarında video, fotoğraf ve metin yoluyla koleksiyon ve hizmetlerini sunabilmektedir. Kullanıcıların arşivlerde erişimlerini desteklemek amacıyla görsel-işitsel tanıtım araçlarının bulunması gerekmektedir. Nitekim Devlet Arşivleri Başkanlığı stratejik planının ihtiyaçlar bölümünde "araştırmacıların araştırma salonundaki sistemi rahat kullanması için tanıtım demosu hazırlanması" (Devlet Arşivleri Başkanlığı, 2019) bu kapsamda değerlendirilmesi gereken bir tanıtım hizmetidir.

Tanıtım faaliyetlerinde yapay zekânın rolü için emsal teşkil etmesi bakımından, kütüphanecilik alanında birtakım uygulamalardan bahsedilmektedir. "Bologna Üniversitesinde yapılan çalışmaya göre robotlar, kütüphaneye gelen yerli ve yabancı kullanıcılar ile tur gruplarını karşılamak ve onlara kütüphaneyi gezdirmek için kullanılabilmektedir" (Öztürk, 2020, s.78) Benzer şekilde arşiv kurumlarına robotik sistemlerin entegrasyonu ile tanıtım faaliyetlerinin sağlanması mümkündür. Bununla birlikte Selçuk'un çalışmasında (2019, s. 54) bahsettiği üzere kütüphane ve bilgi merkezleri içerisinde dijital tabelalar yoluyla hem koleksiyon tanıtımı hem de karşılama ve yönlendirme yardımları sağlanabilmektedir. $\mathrm{Bu}$ amaç ile hazırlanacak araç gereçlerin teknik alt yapısının yapay zekâ destekli olması göz önünde bulundurulmalidır.

\section{Mesleki Değişim}

Mesleki değişim noktasında arşivciliğin temel bileşenlerinden olan; mevzuat, standartlar, araştırma hizmetleri ve faaliyetleri ile yapay zekânın olası etkileri ele alınmaktadır. Birçok meslek alanının artık temel bileşeni sayılması gereken 'teknoloji' de bu kapsamda değerlendirilmektedir.

Öncelikle Cumhurbaşkanlığı kararnamesinin 4. Maddesinin b fikrasında tanımlanan arşivcinin yeterlilikleri ve yetkinliklerinin gözden geçirilmesi gerekmektedir.

b) "Arşivci: Arşiv bilimi ve arşivcilik meslek ilkeleri çerçevesinde belgelerin belirlenmesi, tanımlanması, tasnifi, korunması ve erişim işlemlerini yerine getiren kişiyi” tanımlamaktadır. Arşivci, teknolojiyi etkili olarak kullanma becerisine sahip bir veri yöneticisi pozisyonunda olmalıdır. Bununla birlikte dijital çağda yaşanan gelişmelere, uyum sağlayacak düzeyde yeniliklere açık olmalıdır. Özdemirci'ye göre (2019, s.175) "arşivci, 'veri bilimci + veri yöneticisi' olmalıdır ve olacaktır". Nitekim kararnamenin 4. maddesinde yer alanda fikralarda "Devlet Arşiv Veri Merkezinin" kurulmasından bahsedilmektedir. Kurulacak veri merkezi içerisinde arşivci ancak bir veri yöneticisi olmalıdır. 11 sayılı Cumhurbaşkanlığı Kararnamesi’nin 4. Maddesinin 1 fikrasında (Devlet Arşivleri Başkanlığ̀ Hakkında Cumhurbaşkanlığı Kararnamesi, 2018) belirtildiği üzere

1) "Devlet Arşiv Veri Merkezi: Kamu kurum ve kuruluşları tarafindan üretilmiş belgelerin bir sistem içerisinde saklandığı ve kontrollü bir şekilde erişildiği merkez" olarak tanımlanan yeni bir birimi tanımlamaktadır. Yine kararnamede bu birime ilişkin Devlet Arşivleri Başkanlığı'nın görevleri 5. maddenin e fikrasında (Devlet Arşivleri Başkanlığı Hakkında Cumhurbaşkanlığı Kararnamesi, 2018)

e) "Devlet Arşiv Ağını ve Devlet Arşiv Veri Merkezini oluşturmak, koordine etmek araştırmaya açık bilgi ve belgeleri kullanıma sunmak" olarak açıklanmıştır. Bu merkeze benzer yaklaşım Özdemirci tarafından (2019, s.171) "Milli e-Arşiv Bilgi Sistemi Ağı ve Veri Merkezi" olarak tanımlanmıştır. Yapay zekâ ve makine öğrenmesi, robotik vb. yeni teknolojilerin arşiv süreçlerinde uygulanmasını dile getiren Özdemirci önermiş olduğu merkezi 5 modüler yapı etrafin toplamıştır. 
DAB 2020-2024 Stratejik Planında (2019, s. 43) bu merkeze ilişkin h-1/4 (Hedef 1.4): "Devlet Arşiv A ̆̆l ve Devlet Veri Merkezi kurulmak suretiyle arşiv belgelerinin tek bir sistem üzerinden kolay ve hizlı erişimi sağlanacaktır" hedefi belirlenmiştir. Mevzuatta adı geçen bu merkeze ilişkin çalışmaların devam ettiği ilgili planda mevcut olmasına rağmen henüz somut bir gelişme görülmemektedir. Böyle bir veri merkezinin teknik ve donanımsal altyapısının güçlü bir temel dayanması gerekmektedir. Tüm kamu kurumlarının mevcut belge dolaşımı göz önünde bulundurulduğunda devasa hacimde belgenin yönetilebilir ve arşivlenebilir bir sistematiğe sahip olması beklenmektedir. Bu doğrultuda yapay zekâ uygulamalarından etkin bir şekilde faydalanmak iş ve yönetim süreçlerine hızlı, kolaylık ve doğruluk gibi temeller ile sağlam bir altyapıya oturtulmasına katkı sağlayacaktır. Dolayısıyla veri merkezi, yapay zekâ temelli olan veri bilimi, siber güvenlik, robotik vb. teknolojileri bünyesinde barındırması gerekmektedir.

Mevzuata ilişki önemli bir diğer husus Cumhurbaşkanlığı kararnamesinin Bilgi İşlem ve Elektronik Arşiv Daire Başkanlığının bölümünün 11. maddesinin b ve ç fikralarında (Devlet Arşivleri Başkanlığı Hakkında Cumhurbaşkanlığı Kararnamesi, 2018) belirtilen güvenlik meselesidir.

b) “Başkanlı̆̆ın bilgi güvenliği politikasını oluşturmak

c) Başkanlı̆̆ın sisteminde bulunan verilerin güvenliğini sağlamak"

Verilerin güvenliğini sağlayacak teknik ve yazılımsal altyapı güncel teknolojiye uyumlu olarak geliştirilmelidir. Bununla birlikte bilgi güvenliği politikasının kurumsal fayda göz önünde bulundurarak siber güvenlik teknolojisinden faydalanılması ve bilgi güvenliği araçlarının yapay zekâ destekli bir temele dayandırılması gerekmektedir. Yine stratejik planda bu güvenlik politikasının ISO 27001 Bilgi Güvenliği Yönetim Sistemi’ne göre oluşturulması gerektiği belirtilmiştir. Nitekim Gemci (2010, s.48) tarafından hazırlanan doktora çalışmasında ISO standartlarına uygun uzman bir Bilgi Güvenliği Yönetim Sistemi yazılım modeli önerilmiştir.

İlgili kararnamenin d fikrasında belirtildiği üzere iş birliği ile ilgili açıklamalar madde 21 'de (Devlet Arşivleri Başkanlığ1 Hakkında CB Kararnamesi, 2019) "başkanlık, görev alanına giren konularda bakanlık, kamu kurum ve kuruluşları, kamu iktisadi teşebbüsleri ve kamu kurum niteliğindeki kuruluşlar ile yakın iş birliği içinde bulunur" olarak belirtilmiştir. İç ve dış paydaşların Bilgi İşlem ve Elektronik Arşiv Daire Başkanlığ 1 ile kurumsal amaç ve hedefler doğrultusunda doğrudan iş birliği kurmalıdır. TÜBİTAK, BTK, Sanayi ve Teknoloji Bakanlığı, Ulaştırma ve Altyapı Bakanlığı ve Üniversitelerin ilgili destek bölümleri ile yapılacak iş birlikleri, arşiv hizmetlerinin teknoloji temelli olarak gelişmesine katkı sağlayacaktır.

2020 yılında "Arşivci” meslek standardı, Mesleki Yeterlilik Kurumunun onayı alınarak resmî gazetede yayımlanarak yürürlüğe girmiştir. İlgili standartta arşivci ve arşivcilik ile ilgili açıklamalar genellikle arşivciliğin fiziki ortamdaki iş ve işleyişi ile ilgili bölümleri kapsamaktadır. Dijital araştırma hizmetleri ve dijital erişim araçlarının kapsamlı bir şekilde ortaya konularak bu hizmetlerden sorumlu olan arşivcinin sahip olması gereken beceri ve yeterliliklerin tekrar gözden geçirilmesi gerekmektedir. Hazırlanmış olan mesleki standartta arşivcinin sahip olması gereken beceriler teknolojik gelişme ve yenilik esaslı olarak bahsedilmemektedir. Arşivcinin yapay zekâ temelli olarak sahip olması gereken yeni becerilerin (kodlama, robotik, veri bilim vb.) arşiv iş süreçlerindeki rollerinin ve katkılarının değerlendirilmesiyle mesleki bilgi ve uygulama becerilerine entegre edilmesi gerekmektedir. Meslek standardı başta olmak üzere güncel mevzuatlarda da gerekli düzenlemeler bir eksiklik olarak kendisini göstermektedir.

Araştırma hizmet ve faaliyetleri noktasında arşivlerde kullanıcılar için en önemli sorun ihtiyaç duyulan bilginin nerede olduğunu tespit etmek ve nasıl erişileceğinin bilinmemesidir. Kullanıcılar bu noktada desteğe ihtiyaç duymaktadır. Devlet Arşivleri Başkanlığı'ndan uzaktan erişim ile BETSİS sistemi üzerinden araştırma yapmak isteyen kullanıcılar, Osmanlı, Cumhuriyet ve Dışişleri Bakanlığı arşiv bölümleri olmak üzere üç arşivde araştırma yapabilmektedir. Basit ve detaylı arama yapabilme seçeneklerinin yanı sıra profil bilgileri (kişisel bilgiler, çalışma listesi, belge işlemleri), çalışma bilgileri (çalışma listesi tanımlama ve çalışma listeleri) ve belge işlemleri (son aramalar) seçenekleri bulunmaktadır. Basit arama ara yüzünde sorgulanan anahtar kelimeler doğrultusunda ilgililik esasına göre çok miktarda sonuç çıkarken detaylı arama ara yüzünde arşiv türü bilgisi, fon bilgisi, tarihi bilgisi ve kod bilgisi (defter no., dosya no. vb.) ile anahtar kelime bilgisi gibi birçok farklı bilgi gerekmektedir. 
Araştırma sürecinde bilgiye erişimi, karmaşık zor ve zaman kaybettirici bir duruma düşüren bu işlemler için destek alma ihtiyacı doğmuştur. Bu desteğin araştırma hizmetlerinde chatbot yazılımları ile etkili olabilmesi düşünülebilir. Bankalar ve telekomünikasyon şirketleri hizmetlerini sesli yanıt sistemine dayalı chatbotlar üzerinden gerçekleştirmektedirler. Kütüphaneler ve birçok bilgi merkezlerinde de chatbot kullanımının bulunduğundan bahsedilmektedir. Uzman bir sistem gibi doğal dil işleme teknolojisi desteğiyle "cümleleri tanımlamak, soruları cevaplamak ve karar vermek üzere içine gömülü olan bilgiyi kullanan chatbotlar, tamamen metin tabanlı bir kullanicl ara yüzüne dayandırllarak oluşturulmakta, kullanıcıların komut yazmasına ve konuşmayı metin olarak yanıtlamasına imkân tanımaktadır" (Özkol, Doğan ve Köseali 2019, s. 240-241). Yapılan bu işlem dijital danışma hizmetlerine örnek olarak gösterilebilir. Arşivciyi taklit eden Chatbot örnekli olarak bir uzman sistemin bu doğrultuda geliştirilmesi arşivlerde dijital araştırma hizmetlerine önemli katkıda bulunacaktır.

Kullanıcının sorduğu sorular, yapılan görüşmeler ve çalışma/ilgi alanının belirlenmesinin ardından kullanıcı hakkında yeterli miktarda veri oluşmaktadır. Nitekim BETSIS üzerinden çalışma konuları, çalışma listeleri ve son arama bilgileri yer almaktadır. Elde edilen veriler doğrultusunda arşiv mevcudu içerisinde ilgili yönlendirmelerin yapılabilmesi arşivlerde araştırma hizmetlerine yeni bir boyut kazandıracaktır. Nitekim "academia" gibi platformlar araştırmacıların çalışma ve taramaları doğrultusunda ilgili olabilecek çalışmalar için bildirim atması bu çerçevede gösterilebilecek en iyi örneklerdendir.

Son olarak teknoloji, arşiv iş süreçleri ile hizmet faaliyetlerinin sunumunda kullanılan geniş kapsamlı bir bileşendir. Arşiv hizmetlerine uzaktan erişim sunucuları vasıtasıyla elektronik ortamda erişim sağlanmaktadır. Dijital olarak sunulan bu hizmetlerin iyileştirilmesi için yapay zekâ uygulamalarından da faydalanılmalıdır. Bu teknolojik altyapının fiziki mekândaki araştırma salonları içerisinde hem donanımsal olarak hem de yazılımsal destek ile sağlanması gerekmektedir. Arşiv hizmet salonları içerisinde, dijital tabelalar, dijital el kitapları, kataloglar ve dizinler yer almalıdır. Bununla birlikte özel konu ve/veya fon başlıklarının tanıtımının sağlanması için video rehberlerinin hazırlanması teknolojinin etkililiğini somutlaştırmak adına önemli bir gösterge olacaktır. Tüm bu plan ve düşüncelere, modern teknolojinin dönüm noktası sayılan yapay zekâ teknolojileri entegre edilerek, arşiv hizmet ve faaliyetleri daha etkili olacaktır. Arşivci meslek standartının "Kullanılan Araç Gereç ve Ekipmanlar" bölümünde "bilgisayar ve mesleki yazılımlar", "dijitalleştirme ekipmanları (tarayıcı, kamera, fotoğraf makinesi ve benzeri)" ve "iklimlendirme cihazları" (Arşivci Ulusal Meslek Standard1, 2020) yapay zekâ destekli bir teknolojik altyapıya sahip olmalıdır.

\section{Sonuç ve Öneriler}

Kültürel bellek kurumlarımızdan arşivlerin gelişmesi, artık geleneksel unsurlardan ziyade çağın gereklerine uygun teknolojik ilerlemelerin takibi ve adaptasyonu ile mümkündür. Arşiv kurumlarında teknoloji, diğer bilgi merkezlerinde olduğu gibi tüm süreçleri etkileyebilecek bir unsurdur. Bu unsur her geçen gün değişen ve gelişen dinamik bir yapıyla kurumları yapay zekâ kullanmaya mecburi kılmaktadır. Bundan dolayı arşivler, yapay zekâyı kullanarak sağlamış olduğu avantajlardan en üst düzeyde faydalanmalıdır. Arşivcilikte yapay zekâ kullanımının incelendiği bu çalışmada elde edilen sonuçlar aşağıda sıralanmıştır.

1. Literatürde ifade edilen az sayıda örnek yapay zekâ teknolojilerinin uygulamadaki ilk kullanımlarındandır. Dolayısıyla yapay zekâ uygulamalarının arşivcilikte kullanımı yaygın olmamakla birlikte üzerine durulması gereken bir konu olduğu görülmektedir.

2. Yapay zekâ uygulamalarının arşivcilikteki kullanımı, elektronik ortamda üretilen ve sonradan dijitalleştirme işlemleri sonucu elektronik ortama aktarılan arşiv belgeleri üzerinde uygulanabilir. Temel arşiv iş ve işlemlerinde kullanılan örnekleri değerlendirildiğinde; bu teknolojilerin arşivcilikte zamandan tasarruf ile hızlı bir iş kabiliyeti, otomasyona dayalı iş süreciyle otonom çalışma yapısı gibi birçok avantaj sağlayacağı görülmektedir. Yapay zekâ uygulamalarının hemen hemen tüm arşivcilik süreçlerinde uygulanabilmesi bahsedilen örnekler doğrultusunda mümkün iken sağduyuya ve deneyime dayalı arşivsel işlemler için geliştirilmeye muhtaçtır. Bu noktada yapay zekâ uygulamalarının belgeye ilişkin konu, içerik, bibliyografik bilgiler, üst veri bilgileri, özetleme işlemleri, dil vb. bilgileri çıkararak belirli işlemlerde ancak yardımcı olarak kullanılabilir. 
3. Yapay zekâ uygulamaları kullanılarak arşiv kullanıcısına uzaktan erişim sürecinde danışma hizmeti alabilmesini sağlayacak uygulamalar geliştirebilmesi örneklerden anlaşılacağı üzere mümkündür. Uzman sistem yardımlı chatbot teknolojileriyle arşiv kurumları kendi dermelerine entegre bir sistem kurarak arşiv personeli olmaksızın böyle bir hizmet sunabilmesi mümkündür. Bilgi güvenliği konusunda yapay zekâ, yeni teknolojiler yardımıyla etkili bir koruma sağlamaktadır. Bu noktada büyük bir değişim olarak adlandırılan blokzincir teknolojisi yapay zekâ destekli bir teknoloji olarak yerini almaktadır.

4. Arşivcilikte personel değişimine bağlı olarak işlemler aksamaya uğramaktadır. Yapay zekânın sağlamış olduğu en önemli katkılardan birisi de bu boşluğun meydana getireceği sorunların oluşmasına engel bir yapı inşa etmektir. Yapay zekâ, tıpkı bir arşivci insan gibi daha önce karşılaştığ 1 veriler ile algoritmaların eğitilmesini sağlar ve deneyimleyerek devam ettirir. Dolayısıyla kurumsal işleyişin sürdürülebilirliğine katkıda bulunur.

5. Arşivci meslek standardı ve arşivcilik mevzuatlarında yapay zekâ konusuna dair doğrudan veya dolaylı bir ilişki bulunmamaktadır. Bu iki düzenleyici unsura bağlı olarak arşivcinin yapay zekâya dair mevcut bilgi, beceri ve farkındalıkları yetersiz kalmaktadır.

6. Yapay zekânın arşivcilikte kullanılması ile ilgili yol gösterici nitelikte bir çalışma bulunmamaktadır. Literatürde bahsedilen çalışmalar kısmi konuları ele almakla birlikte kapsamlı bir çalışma yoktur.

Ortaya çıkan sonuçlar çerçevesinde arşivlerde yapay zekânın etkili olarak kullanılabilmesi için geliştirilebilecek öneriler şu şekildedir:

1. Ulusal arşiv politikamızın belirleyicisi $D A B$ ile yapay zekâ uygulamalarının öncü kurumu CBDDO arasında iş birliği sağlanıp "Arşivcilikte Yapay Zekâ Stratejisi”" oluşturularak ulusal arşiv politikası olarak geliştirilmeli ve bu alanda yerini almalıdır.

2. Hazırlanacak strateji planı ve politikası doğrultusunda teknik altyapının (donanımsal, yazılımsal, personel vb.) DAB iç ve dış paydaşlarından TÜBİTAK, BTK, Üniversiteler (Ankara Üniversitesi, Hacettepe Üniversitesi) ortaklığı ile tesis edilmesine yönelik iş birliği protokollerinin hazırlanarak ilgili kurumlarla görüşmeler yapılmalıdır.

3. Arşiv personeline yapay zekâ konusunda bilinçlendirme ve eğitim faaliyetleri düzenlenerek, meslek standardının yapay zekâ uygulamalarına uygun yeni beceriler ile düzenlenmesi gerekmektedir. Arşivcilik eğitimi de veren "Bilgi ve Belge Yönetimi” bölümlerine bu kapsamda bilgilendirici seminerler düzenlenerek, arşivcilik eğitim müfredatı gözden geçirilmelidir.

4. Arşivlerde kullanılacak olan yapay zekâ uygulamalarının seçiminde; arşivcilik ve bilgi teknolojileri konusunda bilgi, deneyim ve eğitimlere sahip arşiv personelinin yer alması daha verimli yapının kurulması için dikkate alınmalıdır.

5. Arşivlerde yapay zekânın kullanılması hem mevzuat hem de standartlara uygun olarak yürütülmelidir. $\mathrm{Bu}$ noktada mevzuat ve standartların yapay zekâya uyumlu bir şekilde güncelleştirilmesi gerekmektedir. KVKK 'nın 7. maddesi gereği verinin silinmesi ve yok edilmesi gibi hata ve yanlışlıkların hukuki sorumlulukları belirlenmelidir. Yine KVKK'nın 11. Maddesinin g fikrasında "İslenen verilerin münhasıran otomatik sistemler vasitasıly analiz edilmesi suretiyle kişinin kendisi aleyhine bir sonucun ortaya çıkmasına itiraz etme" hakkı göz önünde bulundurulması gereken bir noktadır. Benzer hukuki düzenlemelerin dikkate alınması önemlidir.

6. Devlet Arşivleri Başkanlığı ile Savunma Sanayi Başkanlığı iş birliğinde yürütülecek BAYS (Bütünleşik Arşiv Yönetim Sistemi) Projesi'nde yapılandırılan "Devlet Arşiv Ağı” ve "Devlet Arşivi Veri Merkezi" kurularak, dijital ortamda üretilen belge miktarının hacimsel büyüklügü göz önünde bulundurulduğunda; yönetilebilir bir sistemin kurulması için yapay zekâ teknolojileri kullanılmalıdır.

7. Arşivcilikte yapay zekâ kullanımını anlatan, geniş kapsamlı rehberler ve yol gösterici kılavuzlar; basılı ve elektronik ortam, yaygın kullanıma sahip çeşitli diller (İngilizce, Rusça, Arapça vb.) ve farklı kullanıcı grupları dikkate alınarak hazırlanmalıdır.

8. Arşivcilik alanında uluslararası öneme sahip öncü kurumların yapay zekâ konusundaki çalışmaları takip edilerek iş birliklerinin oluşturularak, bu anlamda ulusal ve uluslararası bilimsel toplantılar (kongre, sempozyum vb.) düzenlenmelidir. 
Arşivlerde yapay zekâ uygulamalarının kullanılmasıyla; iş ve işlemlerin kolaylaşması başta olmak üzere; otonom sistem yapısının kurulması ile işgücüne olan ihtiyacın azalması, kurumdaki yönetsel/idari ve iş süreçleri daha doğru ve az maliyet ile yürütülmesi, belgelerin arşivlenmesinde yaşanan karmaşık durumun ortadan kaldırılarak kullanıcılara kolay ve hızlı erişilebilir arşiv sunmak olarak sıralamak mümkündür.

Arşivlerde yapay zekânın kullanılmasında; başta arşivcilere ve arşiv yöneticilerine büyük sorumluluklar düşmektedir. Bununla birlikte Türkiye'de arşivciliğin öncü kurumu olan DAB, yapay zekâ kullanımı konusunda yol gösterici bir role sahip olması beklenmektedir. Ayrıca yapay zekânın arşiv süreçlerinde kullanılmasının teknik, etik ve toplumsal etkileri hakkındaki tartışmaların gerçekleştirilmesinden rahatsız olunmamalıdır (Colavizza vd. 2021, s. 12). Son olarak arşiv-yapay zekâ konusunda gerek teorik gerekse uygulamada yapılacak çalışmalar, arşivlerin hem bugününe hem de yarınına değer katacaktır.

Arşivcilik alanında yazılım-uygulama geliştirme faaliyetlerinde bulunan şirketlerin pazar büyüklüklerinin ortaya konulması bu noktada cevaplanması gereken önemli bir soru olarak ortaya çıkmaktadır. Bu konu, başka bir çalışmanın konusunu oluşturduğundan dolayı ayrıca ele alınmalıdır.

\section{Etik Standartlar ile Uyumluluk}

Çıkar Çatışması: Yazar herhangi bir çıkar çatışmasının olmadığını beyan eder.

Etik Kurul İzni: Bu çalışma için etik kurul iznine gerek yoktur.

Yazar Katkı Beyanı: Makale tek yazarlıdır.

Finansal Destek: Yoktur.

\section{Teşekkür}

Bu çalışmanın gerçekleştirilme sürecinde sağlamış olduğu büyük destek ve katkılardan dolayı sayın Prof. Dr. Fatih Rukancı'ya teşekkür ederim.

\section{Kaynakça}

Abualigah, L. M. Q. ve Hanandeh, E. S. (2015). Applying Genetic Algorithms to Information Retrieval Using Vector Space Model. International Journal of Computer Science, Engineering and Applications, 5(1), 19-28.

Adal1, E. (2012). Doğal Dil İşleme. Türkiye Bilişsim Vakfi Bilgisayar Bilimleri ve Mühendisliği Dergisi, $5(2), 1-19$.

ARCHANGEL. Trusted Digital Archives. Erişim adresi: http://www.archangel.ac.uk/

Ardıç, S. (2014). Yapay Sinir Ağları Kullanılarak Santrifüj Pompalarda Performans Tayini. Yayımlanmamış Yüksek Lisans Tezi, Eskişehir Osmangazi Üniversitesi, Fen Bilimleri Enstitüsü, Eskişehir.

Arslantekin, S. (2003). Veri Madenciliği ve Bilgi Merkezleri. Türk Kütüphaneciliği, 17(4), 369-380.

Arşivci Ulusal Meslek Standardı (2020, 21 Şubat). Resmî Gazete (Sayı: 31046 (Mükerrer)). Erişim adresi: https://www.resmigazete.gov.tr/arsiv/18550.pdf

Binici, K. (2019). Makine Öğrenmesi Yaklaşımılla e-Belgelere Standart Dosya Plan Numaralarının Otomatik Olarak Atanması Üzerine Bir Çalışma. Bilgi Yönetimi, 2(2), 116-126.

Bohyun Kim. (2021). Machine Learning for Libraries and Archives. Online Searcher, 45(1), 39-41.

Bui, T., Cooper, D., Collomosse, J., Bell, M., Green, A., Sheridan, J. ve Brown, A. (2019). Archangel: Tamper-Proofing Video Archives Using Temporal Content Hashes On The Blockchain. Conference on Computer Vision and Pattern Recognition Workshops (s. 2793-2801) içinde. California, ABD: IEEE/CVF. Erişim adresi: https://arxiv.org/pdf/1904.12059.pdf 
Colavizza, G., Blanke, T., Jeurgens, C. ve Noordegraaf, J. (2021). Archives and AI: An Overview of Current Debates and Future Perspectives. arXiv preprint arXiv:2105.01117. Erişim adresi: https://arxiv.org/ftp/arxiv/papers/2105/2105.01117.pdf

Çiçek, N. ve Sağllk, Ö. (2019). Blokzincir Teknolojisinin Elektronik Belgelerin Güvenilirliğinin Korunmasında Başarıya Katkısı. Yalçınkaya B. (Editör), Ünal M. A. (Editör), Yılmaz B. (Editör), Özdemirci F. (Editör) Bilgi Yönetimi ve Bilgi Güvenliği (s. 141-170) içinde. Ankara: Ankara Üniversitesi.

Çil, A. E. ve Aydın, M. (2019). Kurum İçi Uygulamaların EBYS ile Entegrasyonunda Yapay Zekânın Önemi Üzerine Bir İnceleme. Yalçınkaya B. (Editör), Ünal M. A. (Editör), Yılmaz B. (Editör), Özdemirci F. (Editör) Bilgi Yönetimi ve Bilgi Güvenliği (s. 197-209) içinde. Ankara: Ankara Üniversitesi.

Çoban, T. (2018). Sinemada Yapay Zekâ. Yayımlanmamış Yüksek Lisans Tezi. Ordu: Ordu Üniversitesi, Sosyal Bilimler Enstitüsü.

Dearstyne, B. W. (2001). Arşivsel Girişim: Modern Arşivcilik Illkeleri, Uygulamaları ve Yönetim Teknikleri. (Çev. Akbulut, M. ve İcimsoy, A. O) İstanbul: American Library Association.

DeSalvo, D. A. ve Liebowitz, J. (1986). The Application of an Expert System for Information Retrieval at the National Archives. Telematics and Informatics, 3(1), 25-38.

Devlet Arşiv Hizmetleri Hakkında Yönetmelik (2019, 18 Ekim). Resmî Gazete (Sayı: 30922 (Mükerrer)). Erişim adresi: https://www.resmigazete.gov.tr/eskiler/2019/10/20191018-9.pdf

Devlet Arşivleri Başkanlığı Hakkında Cumhurbaşkanlığ Kararnamesi (2018, 16 Temmuz). Resmî Gazete $\quad$ (Sayı: $\quad 30480 \quad$ (Mükerrer)). $\quad$ Erişim https://www.resmigazete.gov.tr/eskiler/2018/07/20180716-1.pdf

Devlet Arşivleri Başkanlığı 2020-2024 Dönemi Stratejik Planı (2019). Ankara: Strateji Geliştirme Dairesi Başkanlığı.

Dolgun, M. Ö., Özdemir, T. G. ve Oğuz, D. (2009). Veri Madenciliğinde Yapısal Olmayan Verinin Analizi: Metin ve Web Madenciliği. Ístatistikçiler Dergisi: Istatistik ve Aktüerya, 2(2), 48-58.

Galiev, A., Prokopyev, N., Ishmukhametov, S., Stolov, E., Latypov, R., ve Vlasov, I. (2018,). Archain: A Novel Blockchain Based Archival System. Second World Conference on Smart Trends in Systems, Security and Sustainability (84-89) içinde. IEEE. Erişim adresi: https://ieeexplore.ieee.org/stamp/stamp.jsp?tp=\&arnumber $=8611607$

Gantz, J. ve Reinsel, D. (2012, The Digital Universe İn 2020: Big Data, Bigger Digital Shadows And Biggest Growth İn The Far East. IDC iView: IDC Analyze the future, 1-16.

Gemci, C. (2010). Uzman Sistem Temelli Bilgi Güvenliği Yönetim Sistemi. Yayımlanmamış Doktora Tezi. Ankara: Gazi Üniversitesi, Bilişim Enstitüsü.

Goodman, M.M. (2019). 'What is on This Disk?' An Exploration Of Natural Language Processing in Archival Appraisal (Yayımlanmamış Lisans Bitirme Tezi). Kuzey Caroline Üniversitesi, Bilgi ve Kütüphane Bilimi Okulu.

Green, A. (2018, 5 Haziran). Trustworthy Technology: The Future of Digital. Erişim adresi:

https://blog.nationalarchives.gov.uk/trustworthy-technology-future-digital-archives/

Green, A., Das, A., Cooper, D., Fawcett, J., Keller, J., Higgins, J., ve Bui, T. (2019). ARCHANGEL: Guaranteeing the İntegrity of Digital Archives. Open Data Institute, The National Archives, University of Surrey. Erişim adresi: https://theodi.org/article/archangel-guaranteeing-the-integrityof-digital-archives/

Greenberg, J. (1998). The Applicability of Natural Language Processing (NLP) to Archival Properties and Objectives. The American Archivist, 61(2), 400-425.

Hawks, C. P. (1994). Expert Systems in Technical Services and Collection Management. Information Technology and Libraries. 13(3), 203-212.

Hirtle, P. B. (1987). Artificial Intelligence, Expert Systems, and Archival Automation. Society of Georgia Archivists, 5(1), 76-88. 
Hutchinson, T. (2020). Natural Language Processing and Machine Learning as Practical Toolsets for Archival Processing. Records Management Journal, 30(2), 1-23.

Kılıç, Ö., Demirtaş, P., Candan, H, Akbayrak, E. H. ve Kutlu, O. (2019) Arşivlerde Yapay Zekâ Uygulamaları: GEODI-Atılım Üniversitesi Kadriye Zaim Kütüphanesi Ankara Dijital Kent Arşivi Örneği Yalçınkaya B. (Editör), Ünal M. A. (Editör), Yılmaz B. (Editör), Özdemirci F. (Editör) Bilgi Yönetimi ve Bilgi Güvenliği (s. 307-324) içinde. Ankara: Ankara Üniversitesi.

Koutroumbas, K. ve Thedoridis, S. (2009). Pattern Recognition. Academic Press.

Küçük, D. ve Arıcı, N. (2018). Doğal Dil İşlemede Derin Öğrenme Uygulamaları Üzerine Bir Literatür Çalışması. Uluslararası Yönetim Bilişim Sistemleri ve Bilgisayar Bilimleri Dergisi, 2(2), 76-86.

Lee, C. A. (2018). Computer-Assisted Appraisal and Selection of Archival Materials. 2018 IEEE International Conference on Big Data. (s. 2721-2724) içinde. IEEE. Erişim adresi: https://ils.unc.edu/callee/p2721-lee.pdf

Lemieux, V. (2016). Blockchain for Recordkeeping: Help or Hype. Teknik Rapor. Vancouver: British Columbia Üniversitesi.

Mandl, T. (2009). Artificial İntelligence for Information Retrieval. Encyclopedia of Artificial Intelligence (s.151-156). IGI Global. Erişim adresi: http://doi:10.4018/978-1-59904-849-9.ch023

Michelson, A. (1991). Expert Systems Technology and Its Implication for Archives. Teknik Rapor. Washington: National Archives and Records Administration. Erişim adresi: https://eric.ed.gov/?id=ED344605

Nabiyev, V. (2016). Yapay Zekâ: İnsan-Bilgisayar Etkileşimi. Ankara: Seçkin Yayıncılık.

Özdemirci, F. (2019). Milli e-Arşiv Bilgi Sistemi Ağı ve Veri Merkezi Yapılanma Önerisi: Yenilikçi Teknolojiler-Yeni Nesil Arşivciler-Yapay Zekâ ve Ötesi... Bilgi Yönetimi, 2(2), 169-176.

Özkol, İ., Doğan, K. ve Köseali, G. (2019). EBYS Uygulamalarında Yapay Zekâ Destekli Chatbot (Sohbet Robotu) Kullanımı. Yalçınkaya B. (Editör), Ünal M. A. (Editör), Yılmaz B. (Editör), Özdemirci F. (Editör) Bilgi Yönetimi ve Bilgi Güvenliği (s. 229-250) içinde. Ankara: Ankara Üniversitesi.

Öztürk, F. (2020). Kütüphanelerde Yapay Zekâ Uygulamaları. Yayımlanmamış Yüksek Lisans Tezi. Ankara: Ankara Üniversitesi, Sosyal Bilimler Enstitüsü.

Payne, N. ve Baron, J. R. (2017, December). Auto-Categorization Methods for Digital Archives. IEEE International Conference on Big Data (Big Data), (2288-2298). IEEE. Erişim adresi: https://ieeexplore.ieee.org/stamp/stamp.jsp?tp=\&arnumber $=8258182$

Pirim, H. (2006). Yapay Zekâ. Journal of Yaşar University, 1 (1), 81-93.

Pratical Guide of Organization, Management and Preservation of Burundi Communes Archives. (2018). International Council on Archives. Erişim adresi: https://www.ica.org/sites/default/files/practical_guide_of_burundi_communesarchives_aprobad.pdf

Rolan, G., Humphries, G., Jeffrey, L., Samaras, E., Antsoupova, T., ve Stuart, K. (2019). More Human Than Human? Artificial İntelligence İn The Archive. Archives and Manuscripts, 47(2), 179-203.

Safalı, Y., Avaroğlu, E. ve Ergen, B. (2018). Twitter Verilerinden Kullanıcıların Siyasi Eğilimlerinin Veri Madenciliği Teknikleri ile Kestirimi. 2018 International Conference on Artificial Intelligence and Data Processing (IDAP) (s. 1-5) içinde. IEEE. Erişim adresi: https://ieeexplore.ieee.org/stamp/stamp.jsp?tp=\&arnumber $=8620747$

Shang, E., Liu, X., Wang, H., Rong, Y. ve Liu, Y. (2019). Research on the Application of Artificial Intelligence and Distributed Parallel Computing in Archives Classification. 4th Advanced Information Technology, Electronic and Automation Control Conference (IAEAC) (s. 1267-1271) içinde. IEEE. Erişim adresi: https://ieeexplore.ieee.org/stamp/stamp.jsp?tp=\&arnumber=8997992

Schneider, J., Adams, C., DeBauche, S., Echols, R., McKean, C., Moran, J., ve Waugh, D. (2019). Appraising, Processing, and Providing Access to email in Contemporary Literary Archives. Archives and Manuscripts. 47(3), 305-326.

Seker, S. E. (2015). Metin Madenciliği (Text Mining). YBS Ansiklopedi, 2(3), 30-32. 
Selçuk, N. (2019). Bilgi Merkezlerinde Yapay Zekâ Uygulamaları: Türkiye İçin Durum Analizi Yayımlanmamış Yüksek Lisans Tezi. Çankırı: Çankırı Karatekin Üniversitesi, Sosyal Bilimler Enstitüsü.

Standart Dosya Planıyla İlgili 2005/7 sayılı Başbakanlık Genelgesi (2005, 25 Mart). Resmî Gazete https://www.resmigazete.gov.tr/eskiler/2005/03/20050325-10.htm Erişim adresi:

Uzundere, E., Dedja, E., Diri, B., ve Amasyalı, M. F. (2008). Türkçe Haber Metinleri İçin Otomatik Özetleme. Akıllı Sistemlerde Yenilikler ve Uygulamaları Sempozyumu (s.1-4) içinde, Isparta.

Yajian, L., Chuwu, P., ve Luan, H. (2002). Expert-Based Multi-Mode Switching Control for The Temperature and Humidity Control System of Archive Establishment. 4 World Congress on Intelligent Control and Automation (s.858-862) içinde. Shanghai: IEEE. Erişim adresi: https://ieeexplore.ieee.org/stamp/stamp.jsp?tp=\&arnumber=1020695

Yılmaz, A. ve Kaya, U. (2020). Derin Öğrenme. İstanbul: Kodlab Yayınevi. 